\title{
CONF-83r+106- -105
}

DESIGN FOR THE NATIONAL RF TEST FACILITY AT ORNL ${ }^{a}$

H. L. Gardner, D. J. Hoffman, W. R. Becraft, 'ं C. H. Blue, S. K. Combs, W. K. Dagenhart,

H. H. Haselton, P. H. Hayes, J. A. Moeller, ${ }^{C}$ L. W. Oten, N. S. Ponce,

P. M. Ryan, D. E. Schechter, C. R. Stewart, W. L. Stirling,

D. J. Taylor, and J. H. Whealicon

Oak R1dge National Laboratory

Oat RIdge, Tennessee 37830

(615) $574-1121$

COHF $-830406--105$

DE83 017180

\section{DRSCLAIMER}

This report was prepared as an account of work sponsored by an agency of the United States Government. Nejther the United States Government nor any agency thereof, nor any of their employees, makes any warranty, express or implied, or assumes any legal liability or responsibility for the accuracy, completeness, or usefulness of any information, apparatus, product, or process disclosed, or represents that its use would not infringe privately owned rights. Reference herein to anv specific commercial product, process, or service by trade name, trademark, manufacturer, or otherwise does not necessarily constitute or imply its endorsement, recommendation, or favoring by the United States Government or any agency thereof. The views and upinions of authors expressed herein do not necessarily state or reflect those of the United States Government or any agency thereof. 
Eir accoptanco of this articla, tho publishor or rociplent ackinowtadoes tho U.S. Govornmont's right to rotain a nonoxalusivo, royalty-freo fliconso in and to any copyright covaring tha articlo.

W. L. Gardner, D. J. Hoffman, W. R. Becraft, ${ }^{b}$ C. W. Blue, S. K. Combs, W. K. Dagenhart, H. H. Haselton, P. H. Hayes, J. A. Mneller, ${ }^{C}$ L. W. Owen, N. S. Ponte, P. M. Ryan, D. E. Schechter, C. R. Stewart, W. L. Stirling,

D. J. Taylor, and J. H. Whealton

Oak RIdge National Laboratory

Oak Ridge, Tennessee 37830

(615) $574-1121$

\section{ABSTRACT}

Conceptual and prellminary engineering design for the National RF Test Facility at Oak Ridge National Laboratory (ORNL) has been completed. The facilicy will comprise a single mirror conflguration embodying two superconducting development coils from the ELMo Bumpy Torus Proof-of-Princtple (EBT-P) program on either side of a cavicy designed for full-scale antenna testing. The coils are capable of generating a 1.2-T field at the axtal midpoint between the coils separaced by $1.0 \mathrm{~m}$. The vacuum vessel will be a stainiess sceel, wacercooled structure having an 85-cm-radius central cavity. The facility will have the use of a number or continuous wave $(\mathrm{Cw})$, radio-frequency (ri) sources at levels including $600 \mathrm{kH}$ at $80 \mathrm{MHz}$ and $100 \mathrm{kH}$ at $28 \mathrm{GHz}$. Several plaswa sources will provide a wide range of plasma environments, including denstries as high as $0,5 \times 10^{13} \mathrm{~cm}^{-2}$ and temperatures on the order of $210 \mathrm{eV}$. Furthermore, a wide range of dlagnostics will be available to the experimenter for accurate appraisa: of rf testing.

\section{INTRODUCTION}

Radio-frequency $\left(r \bar{F}\right.$ ) heating experlence ${ }^{i-3}$ on major conffnement devices has demonstrated the necessity of developing and testing certain components on racilities off line from the physics experiment. As larger, longer pulse experiments are proposed to be performed in reactorlike plasmas, it inas become clear that caresui attention must be paid to the technology developmant needs. A national if program plan

\footnotetext{
Research sponsored by the office of Fusion Energy, U.S. Department of Energy, under contract if-7405-eng-26 with the Unfon Carbide Corporation.

General Electri= Compan;.

Grumpan terospace Corporation.
}

1dentiffes the desirabillty of an $r i$ test facllicy dedicaced to the development and assessment of rf systems and components.

The JRNL facility, as presently envisioned, will foster the development of reactor-relevant components and will provide suffictent volume to test full-scale components for such devices as PLT, TFTR, D-III, ATF, MFTF-B, and TMX-Upgrade. In addition to allowing more efficient use or confinement device operating time, the greater physlcal access and experimencal availabilicy made possible by a dedicated test facility will provide the opportunity not only for a more careful assessment and diagnosis of $r$ system components, but also for the testing and evaluation of cheoretical models of launcier/plasma interaction.

The key Eeatures of the ORVL cest faciility are the presence of a plasma load and the availability of $\mathrm{cw}$, high power if sources over a wide range of frequencies. The $\mathrm{cw}$, high power sources enable (1) testing of component power handling capabilities, thermal cycling, Latigue, and sulfability of materlals, (2) assessment of cooling requirements and fabrication techniques, and (3) creacment of generic syscems problems. The plasma environment is necessary to duplicate the low radiation resistance and time-varying VSWRs encountered on confinement experiments. Furthermore, the presence of a plasma is necessary for evaluating the properties and perzormance of such components as Faraday sinields, current feeds, couplers, insulators, windows, and waveguides.

\section{EACILITY DESCRIPTION}

The rf rest facility as depicted conceptually in Fig. 1 will be a simple mirror configuration using the two superconducting development colls from the EBT-P program. Given the constraints that these co1ls place on the facillty design, trade-oifs were made to optimize vacuum vessel access, magnetlc í; 


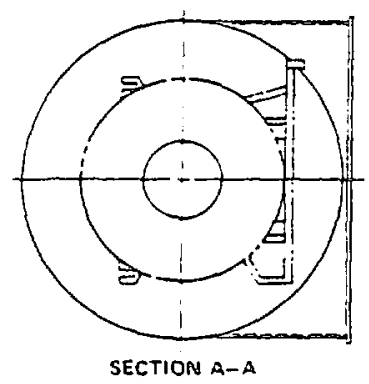

SECTION A-A

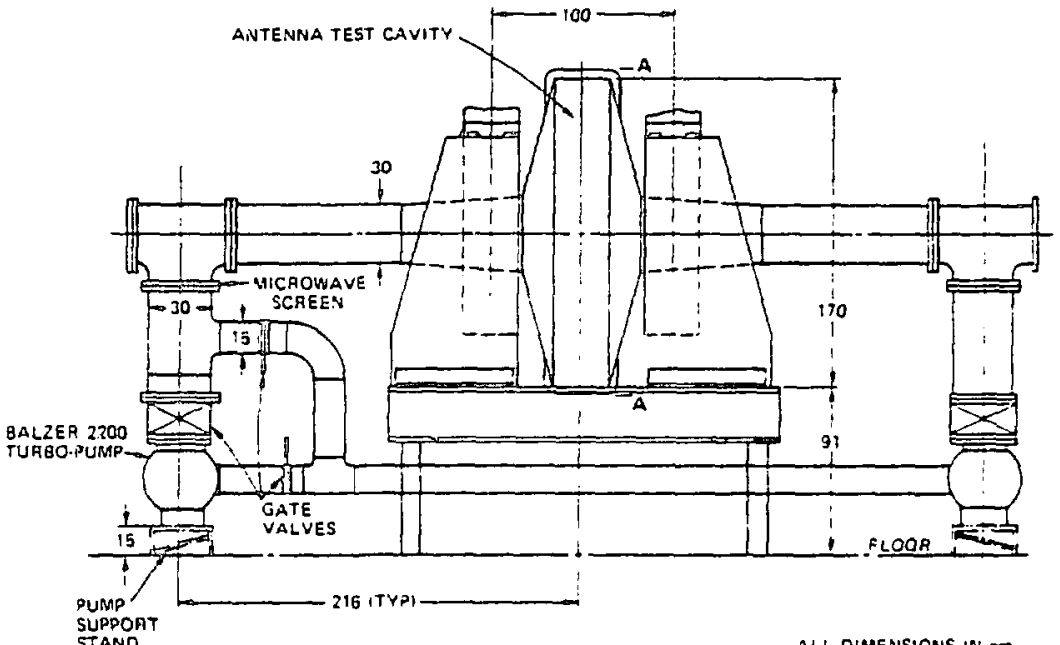

ALL DIMENSIONS IN $\mathrm{cm}$

F1g. i. Conceptual drawing of the ORNL zi test factilty.

strength, cooling of critical surfaces, and vacuum pumping speed. Discussed below are the criteria Eor and descriprions of the nafor subsystems to be incorporated into this facility.

\section{The Magnet System}

to EBT-? derelopment coil as depicted in Fig. 2 has an inner diameter of $43 \mathrm{~cm}$, an outer diameter of $107 \mathrm{~cm}$, and a chickness of $30 \mathrm{~cm}$. Eaci coil seighs $1800 \mathrm{~kg}$. A maximum fleld of 7.4 I can be achieved in each coil, and a raxizum field of $\dot{i}\{\mathrm{~T}$ can be achleved on axis in the tinroat. At this writing the maxtmum field ratings have been achleved in the test of tie first coil. is a compromise between aaincaining the large access necessary to cest fullscale launchers and also maincaining reasonably nigh fleld strengtis, the coils have a 1.0-n tiroat-to-throat separation. This will allow a jaximim Eleld of $1.2 \mathrm{~T}$ at the axial aidyoint between colls. Figure 3 shows the raguetic geometry under maximum field conditions for the inosen coil separation. Cuncours of mod-B are in increments of 0.6 :.

Freilinary tests to determine the cooling zequirements for the coils indicate that approxinately 250 L of liquid helium (Lie) is needed to cool each coil Erom liquid nitrogen $\left(L_{2}\right)$ temperatures and that each will have a boilorf rate of $: .25 \mathrm{~L} / \mathrm{h}$. The Lite system has been conservatively sized for demands about $25 \%$ higher than this. As presently conceived, two pressure-ied :000-i Dewar flasks will provide a continuous flow of Lije to the magnets at a rate mat hed to the total boilorf. The boiloft will be recovered via a compressor, stored, and

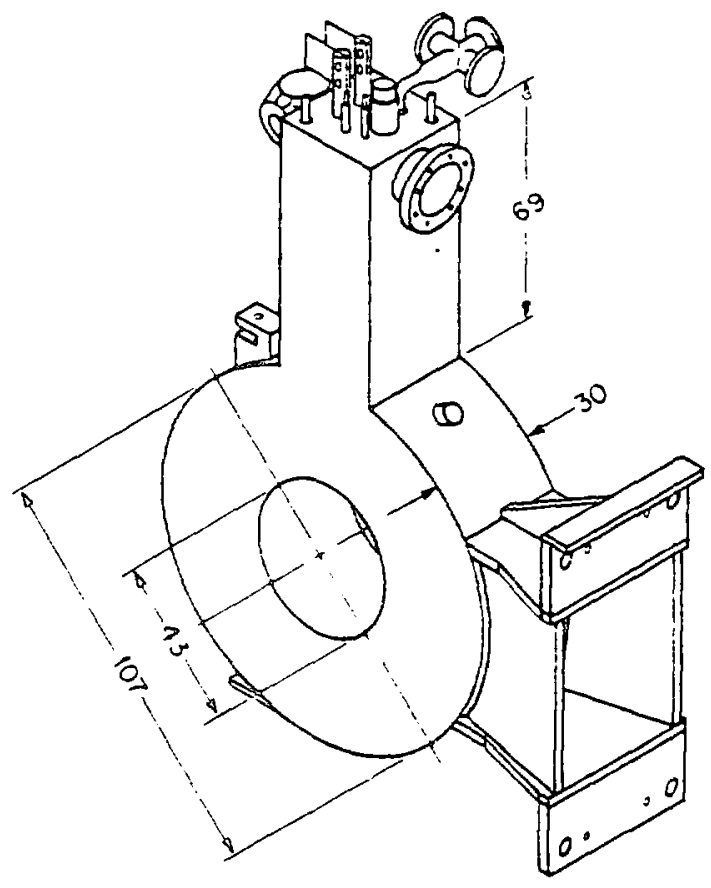

WEIGHT $\sim 1800 \mathrm{~kg} \quad$ ALL OIMENSIONS $\mathrm{IN} \mathrm{cm}$

Elg. 2. Perspel:ive of che test facility voil assembly. 
ORNL-DWG 83-2419 FED

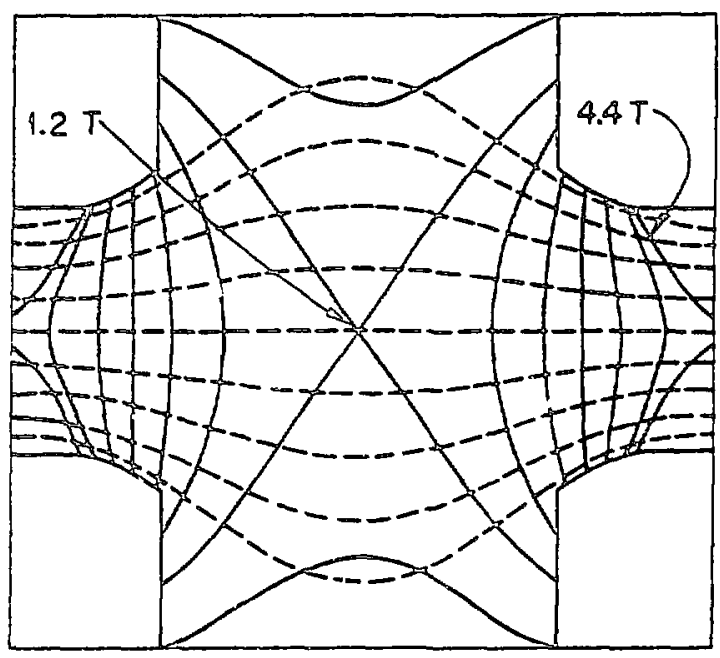

F1g. 3. The magnetic geometry of the test facility coils at maximum field strength. Throat-to-throat coll separation is $100 \mathrm{~cm}$. Dashed curves Indicate field lines; solid curves indicate mod-B contours.

subsequencly rellquefied. Derand for $\mathrm{LV}_{2}$ will be adequately supplied by a 15,000-L canker through vacuum-jackeced cransfer lines to a 500-L internediate storage Dewar Flask and thence to the coils as required. The $\mathrm{LV}_{2}$ system is open ended and vented to the atmospiere.

Electrically the coils will require approximately 1800 i to reach full field. A 12-V, 3000-A dc supply having $<1 \%$ ripple will be available for this purpose. Fully tested quench protection circuitry vill be provided with the coils.

The magnet support scructure for the facility is designed to accomodate 1.5 times the expected full fleld attractive force of $14,500 \mathrm{kG}$.

\section{̈acuum Yessel and Associated Subsystems}

The vacuum vessel design was primarily influenced by the destre to maximize access, yet maintain reasonably high ifeld strengths. Additional design considerations fnclude the physical constraints of the coils, power handiling under full $r \dot{t}$ power loads, and prorection of the vacuum systen turbopums from high aagnetic iflelis.

is indlcated in Fig. 4, the maximun cross section of the cencral celt is a disc $170 \mathrm{~cm}$ in diamere:- The antenna access port is 170 by $46 \mathrm{~cm}$ and is adequate for lnstalling and testing the full-scale prototype antennas planned for current machine upgrades. In addition, enough access is avallable to permit 25 additional dlagnosic ports of various slzes.

The magnetic field configuration is an fmportant consideration in designing and cooling the central cavicy and in placing and shfelding the curbopumps. Figure 3 showed the magnet1c geometry at Full Eleld, but normal operacion will be at approximately 75\% of full field to allow the $28-\mathrm{GHz}$, mod-B resonance surface to extend across the central region of the central cell. As discussed later, intelal plasmas for this facllity will be produced by a $28-\mathrm{GHz}$ gyrotron. Representative mod-a resonance contours are shown in Fig. 4, as are assoctated fleld Iines representing plasma loss pachs to the walls. Cooling is concencraced where chese resonant field lines intersect the vacuum vessel walls as snown. The 1nitial operating phase of this factlity will have the capability of delivering no more than $1 \mathrm{MW}$ of $\mathrm{cw}$ power to the plasma acting as an antenna load. Based upon this 1nput power, cooling has been sized to handle the expected $\sim 15-\psi / \mathrm{co}^{2}$ power density on the walls in the region of miximum plasma loss. Other sectlons have cooling ellities of 4 to $7.5 \mathrm{w} / \mathrm{cm}^{2}$. Each cooling ctrcuit will be monicored calorlaetrically to decermine overall power flow pacterns and ragnicudes. In addlcion, appronimacely 80 chermocouples will be installed along the vessel co permic detailed mapoing of the heat load during operation.

The vacuum system calls for t:00 3000- $/ / \mathrm{s}$ Balzer turbopusps jacked by a single Roors blower-nechanical pump combination. Vacuum dlagnostcs and concrols are based on standard lon and thermocouple gages, vich logic incerlocks controlling electropneumaic valves for - system protection.

The turbopumps provide puaping of the cencral cavisy through long throats and nicrowave screens, as shown in Fig. 4. These long throats and zicrowave screens were desizned to factlicate adequate nagnetic and sicrowave shielding, respectively, for the pumps withou= severely imiting gas conductance from the central cell. In Fact, the vacuum system was sized to handle expected plasna scurce zas loads and raincain a central cell pressure of $\leqslant 10^{-\infty}$ cor:

\section{RF Sources, Plasna Sources, and Diagnoscles}

The If sources available at the test facility to support risst-year operations cover three frequency ranges. There is a $100-\mathrm{kW} \mathrm{cm}$ source adjustaile from 2 to 30 :tiz for ton eyclotron resonance heating (ICRH) studies. it 


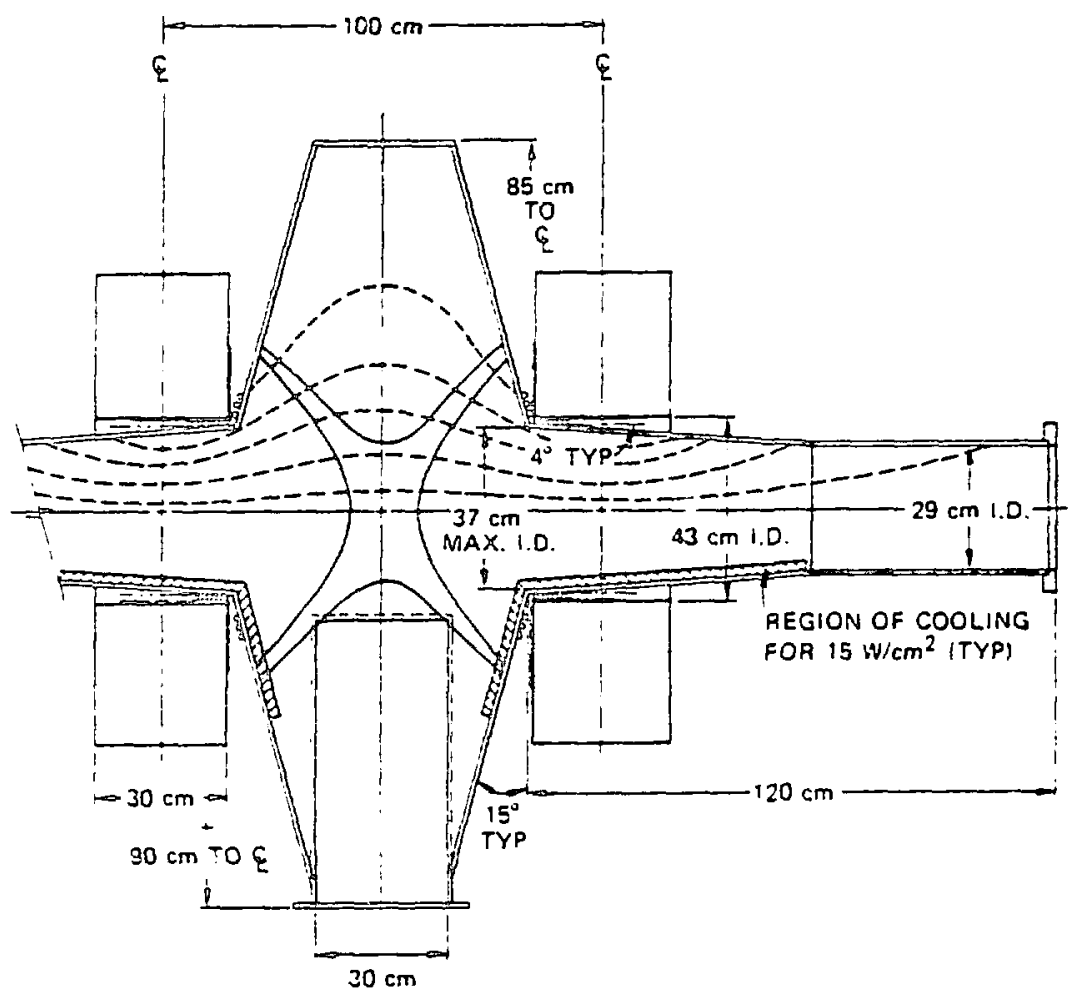

F1g. 4. Tese factlity schematic fndfcating mod-3 surjaces near the 2S-GHiz resonance as well as representative fleld lines along which plasma is lost. Hso show is the area where cooling will be most concentrated.

50-kw ex system adjustable Erom 175 co 215 :Mtz is available for support of East-wave currentdrive experiments. The chird source is a iOD-ish $\mathrm{ct}, 28-\mathrm{GHz}$ jyrotron system that is available for electroa cyclotron resonance heating (ECNH) studies as well as generating a cr plasma load. In addition to these presently available ti systems, JRM is acquiring a Eusion Macerials Irzadtation Test (FNIT) r $\bar{t}$ system capable of $600-\mathrm{kH}$ Cy operation at $30 \mathrm{kHz}$ $i=1-\mathrm{Hz}$ cuning range). Nooizications are veing ivestigaced shat wil: enable operation over the Erequency ranges of 15 to 30 Mtiz (luaped eiemenc) and $30=0$ : $50 \mathrm{NHz}$ (cavity) in addition to its design Erequency.

Eor experimental ilexibility, it douid be desirabie to have 3 plasma source that could be euned over a wide range of density $\left(10^{i 2}\right.$ to $\left.20^{*} \mathrm{~cm}^{-i}\right)$ and temperature $\left(T_{\mathrm{e}}=1-10 \mathrm{eV}\right.$, $I_{i} \cdot i-10 \mathrm{eV}$ ) and would be quiescent, operate continucusiy, requitre ilstle or no gas throughFut, and operate iadependently of the magnetic field strengch. Because a single such source would be impractical, three different types of sources will be used over the near tern to generace a reasonable subset of destrec plasma parameters. Because it is easilv implemented, initlal continuous plasmas with cemperacures of $.10 \mathrm{eV}$ and denstities ot the order of $10^{1:} \mathrm{cs}^{-j}$ will be foraed by cyclotron resonance breakdown using the gyrotron system nentioned above. it waster gur plasma source, though isherently shore puise $(", 3 \mathrm{~ns})$, is expected to produce $\checkmark 10-\mathrm{eV}, .5 \times 10^{i} \bar{i}-\mathrm{cs}^{-j}$ plasmas. The third piaswa source jeing exvisioned for this Eacilfty is a cold cathode arc that is betag designed to produce a localized, continuous, $\because 10-\mathrm{eV}, 110^{i 3}-\mathrm{cm}^{-3}$ plasma. The number of these cold catiode arcs that can be accomodated by the pumping system atll be determined experimentally.

To obtain an accurate appraisai of $r=$ cestiag, a complete diagnostics package is being orepared for the facility. Thus Ear, power loading on the vessel walls and tz 
conponenes will be measured by calorinetry consis-ing of $\Delta T$ rransducers and flotmeters on the vater cooling elrcults. Relative poucr flum aeasurements will be mapped by thermocouples and an infrared camera. Curreat distributions on antennas will be measured with tf current probes and distributed voltage sensors. Electromagnectc fleld quantitles ull be sampled by movable probes such as square-law diodes and ragnetic loops. Plasma densitles will be measured by Langmulr probes and a microtave incerfercmeter, and electron cemperacures w1ll be gaged by opcical spectrometry as well as the Langmulr probes. Data acquisition will be handled by a PDP-11/34 compucer gystem on a shared basis with the present neutral beatn liigh Pouer Test Factlicy. It is expected chat additional diagnostics ylll be added as experimental and testing programs evolve.

\section{REFERENCES}

1. Equipe TFR, pp. 75-84 in Fiasma Fhysice and Controlied Nuclear Eusion Regeanch. Proceedirgs of the 8 th Intemationai Conjerence, Bmusels, 1980, Vol. 2, International Atomic Euergy Agency, Vtenna, 1981.

2. P. L. COLESTOCK et al., paper A3 in Proceedings of the th Topical Conjepence on Radio Frequency ieatine in Dlasmas, Universily of Texas, Austin, 1981.

3. JFT-2 Group, p 259 in seatine in Tcroidai plasmas. Proceecings of the spdi joint Varenna-Grenoile Intemationai Symposium, Comansion of the Eurogean Communities, Brussels, 1982.

4. The Vationat if Tecinnology sesearin and Development Erogran Plan, CONE-820758, to be nubilshed at Oaik Ridge National Laboracory. 